RICHARD N. COOPER

Harvard University

\title{
Dealing with the Trade Deficit in a Floating Rate System
}

The volatility of the dollar in the last several years has led to serious second thoughts worldwide about the desirability of a system of floating exchange rates. The emergence of dissatisfaction was predictable. The exchange rate is the most important price of any nation's economy after the wage rate, and the wage rate is splintered into thousands of fragments. Firms are deeply upset by price movements they do not understand. Economists may have the best of the argument when they say that the total uncertainty in the economic system is not increased by flexible exchange rates, although even that judgment depends on assessments of the extent to which an exchange rate commitment can "discipline" national economic policies and also on the prevalence of autonomous bandwagon movements in the foreign exchange market. But that conclusion is no consolation to those in the goods-producing heart of the economy who feel directly the impact of foreign price fluctuations. For them uncertainty has risen, and I predict that it will prove to be intolerable and that they will insist on political action to reduce it.

Specifically, there will be pressures for protection against sudden and unpredictable foreign competition due to movements in exchange rates. There will also be pressures for controls on capital flows to reduce exchange rate movements. And there will be pressures for direct intervention in currency markets to the same end. Most countries of the world continue to peg their currencies to something, and the creation of the European Monetary System (EMS) also represents a movement away from flexible exchange rates. I have elsewhere suggested that the best way to reduce exchange rate uncertainty is for the industrial democracies to adopt, at a point suitably distant in the future, a single currency. 
In the long meantime, various halfway houses will be sought. The EMS is one illustration. Proposals for reference rates and target zones should be taken seriously and studied carefully, so the recent decision by the Interim Committee of the International Monetary Fund in favor of serious staff work on these questions should be welcome. In the end, however, I suspect that even the more exacting of these schemes will prove to be technically flawed or to entail major loopholes or to fail to cover all of the important possibilities, so that a regime of discretionary and negotiated exchange rate management is what we will have to endure until we are ready for more far-reaching commitments regarding national economic actions. In what follows I discuss how such exchange rate management looks from an American perspective in the spring of 1986.

Although immediate economic prospects for most Americans are reasonably good, the large trade deficit and federal budget deficit pose two serious long-term problems. The weak U.S. export markets and stiff competition from imports that resulted in the large trade deficit have been squeezing employment and profits in American manufacturing and mining. Firms and labor unions are seeking protectionist relief on a scale not seen since 1970, and perhaps not since 1930, when the infamous Smoot-Hawley Tariff Act raised American tariffs to a level second only to that attained under the 1828 Tariff of Abominations. By early 1986 several hundred import-restrictive bills had been introduced in Congress, and one, a comprehensive bill on textiles and apparel, had actually passed, though it encountered a presidential veto. Momentum was mounting for an omnibus trade bill that certainly would have been restrictive in purpose and effect. Such legislation would hurt U.S. consumers and would almost certainly induce other countries with budgetary or competitiveness problems to follow the same course. It thus could lead to a dismantling of the liberal trading regime built so painstakingly since World War II and to increased international political acrimony. Moreover, countries with serious foreign debt burdens would find servicing their debts even more difficult and would be strongly tempted to abandon the effort altogether, thus turning a trade crisis into a financial and a foreign policy crisis as well.

The second problem is that the United States has been building up both its public and its external debt at a rapid rate. Federal debt has grown between 1981 and 1986 from $\$ 1$ trillion to $\$ 2$ trillion, the latter 
figure amounting to about half of gross national product. If debt continues to grow much more rapidly than GNP, an ever larger share of income will eventually have to be taxed in order to service it. Furthermore, much of the debt, or its equivalent in private obligations, is accruing not to Americans but to foreigners, the financial counterpart of the large U.S. trade deficit, which is being financed by borrowing abroad. In 1984 the United States imported (net) $\$ 107$ billion in capital from abroad, more than the entire Brazilian external debt, and in 1985 this figure rose to $\$ 118$ billion. Without corrective action, the United States will have borrowed half a trillion dollars from abroad between 1983 and 1987, a debt that can be serviced only out of future income. That would be no special problem if the foreign funds were being invested at rates of return to American investors in excess of the cost of borrowing. But U.S. domestic investment has not been exceptionally strong in recent years, and the foreign loans have been used to finance public spending with little or no future economic yield.

The United States has in effect borrowed against its future income to enjoy immediate consumption, both public and private. Servicing the external debt will mean lower living standards for the future, both because of interest to be paid to foreign lenders and because of the deterioration in the terms of trade necessary to generate the trade surplus required to service the debt. The primary burden will fall mainly on the working population, which already faces the burden of supporting the growing number of social security recipients.

With its large trade deficit, the configuration of the U.S. economy poses an unacceptable threat to the liberal trading system and imposes an unwarranted burden on future generations of Americans. This says nothing of the anomaly, from a global perspective, of the world's richest country being the largest net importer of capital. To head off these problems requires a substantial reduction in both the U.S. budget deficit and current account deficit.

\section{Shifts in Policy}

A look at saving and investment in the U.S. economy suggests strongly the desirability of a reduction in the budget deficit. From the national 
Table 1. Relationship between Foreign Investment and National Saving and Investment, United States, Selected Years, 1966-85 ${ }^{\mathrm{a}}$

Percent of GNP

\begin{tabular}{|c|c|c|c|c|c|c|c|}
\hline Year & $\begin{array}{c}\text { Net } \\
\text { foreign } \\
\text { investment }\end{array}$ & $=$ & $\begin{array}{l}\text { Gross } \\
\text { private } \\
\text { saving }\end{array}$ & + & $\begin{array}{l}\text { Government } \\
\text { budget } \\
\text { surplus }\end{array}$ & - & $\begin{array}{c}\text { Gross } \\
\text { domestic } \\
\text { investment }\end{array}$ \\
\hline 1966 & 0.5 & & 17.0 & & -0.2 & & 16.7 \\
\hline 1973 & 0.6 & & 18.0 & & 0.6 & & 17.6 \\
\hline 1979 & 0.1 & & 17.8 & & 0.5 & & 18.1 \\
\hline 1984 & -2.4 & & 18.4 & & -2.9 & & 17.9 \\
\hline 1985 & -2.9 & & 17.4 & & -3.5 & & 16.8 \\
\hline
\end{tabular}

Sources: U.S. Department of Commerce, Bureau of Economic Analysis, The National Income and Product Accounts of the United States, 1929-1982 Statistical Tables, table 5.1 (Government Printing Office, forthcoming), and Survey of Current Business, vol. 66 (March 1986). Figures are rounded.

a. The equation in the table is not exact because it omits the staistical discrepancy in the NIPA.

b. Federal plus state and local surplus.

accounts identity, net foreign investment (approximately the balance on goods and services) must equal the excess of national saving (the sum of private saving and the government surplus) over domestic investment.

As table 1 suggests, gross private saving, including corporate retained earnings and capital consumption allowances, was exceptionally high in 1984, while gross domestic investment at 17.9 percent of GNP was only slightly above normal for a boom year. What was not normal for a boom year was the large public deficit, which absorbed private saving and required an inflow of resources from the rest of the world to cover the normal investment. If the government accounts had been in balance (state and local governments actually showed a surplus of $\$ 64$ billion, or 1.7 percent of GNP, in 1984), the United States on this accounting would have produced a healthy and not abnormal trade surplus in goods and services, about 0.5 percent of GNP. So long as the federal government deficit runs 4 to 5 percent of GNP, the United States can be expected to run a substantial trade deficit except in a period of deep recession, when domestic investment falls way off. It is not realistic to expect an increase in private saving large enough to balance the external accounts, particularly since aggregate private saving is not consistently and predictably responsive to alterations in public policy.

A substantial reduction in the budget deficit, therefore, is a necessary condition for a substantial improvement in the trade balance with the economy operating at anything like current levels of activity. The need for deficit reduction is increasingly recognized, and both Congress and 
the president accept it. Sharp disagreements still exist on how fast the deficit should be reduced and, more important, on how it should be reduced. Moreover, sharp discrepancies between declared policies and actions suggest that skillful political posturing is more important to the key actors than the actions actually taken. Nonetheless, prospects for deficit reductions are much better now than they were a year ago.

In December of 1985 Congress passed and the president signed the Balanced Budget and Emergency Deficit Control Act. The bill, better known as "Gramm-Rudman," sets a series of declining deficit targets starting with $\$ 208$ billion in fiscal year 1986 (a target that would have been $\$ 172$ billion except that required cuts were limited in the first year) and declining to zero in fiscal year 1991. If Congress were actually to meet these deficit targets, the fiscal shift would impose severe contractionary pressures on the U.S. economy that would generate a recession unless offset by sources of demand elsewhere in the economy.

What might these sources be? Further increases in consumption not related to disposable income are unlikely, given the already low household saving rate and the relatively high levels of household debt. That leaves investment and exports as possible sources of demand to offset the contractionary fiscal policy.

Lower interest rates could increase investment, especially housing investment, which in recent years has been below what might have been expected on the basis of new household formation. The drop in longterm interest rates of nearly 300 basis points between early 1985 and early 1986 (most of the decline occurring before the passage of GrammRudman) should stimulate housing construction. Progress in reducing the budget deficit should lead to further easing of long-term interest rates. Short-term Treasury bill rates, by contrast, actually increased modestly from June through December of 1985 after having fallen steeply in April and May. The rising rates suggest a rather firm stance of U.S. monetary policy, even though the M1 money supply continued to grow much more rapidly during 1985 than the 7 percent upper limit set by the Federal Reserve in February of that year. The M2 money supply grew throughout the year near the 9 percent upper limit range. Because inflationary pressures did not reemerge and because sensitive materials prices actually weakened throughout 1985 , it became desirable to ease monetary policy further to stimulate housing construction by the time the budgetary contraction begins to take serious effect in late 1986. And 
indeed in March the Federal Reserve lowered its discount rate, and Treasury bill rates dropped nearly 50 basis points, the largest decrease since June 1985.

\section{The Role of Exchange Rates}

The other component of demand that could in principle and should in practice take up the slack created by fiscal contraction is net exports. There is no shortage of industrial and agricultural capacity to expand exports: despite economic recovery since 1982, the entire U.S. tradable sector has been depressed by foreign competition. The obvious solution to competitiveness problems is a low value of the dollar relative to other major currencies, particularly the yen and the European currencies.

The United States found itself last fall in a situation in some respects analogous to that of many less developed countries: it faced a large payments deficit caused mainly by an expansionist fiscal policy. The important difference was that the U.S. budget deficit had not been monetized-indeed monetary policy had been rather tight-and the United States had been able to finance its current account deficit by borrowing abroad. (With flexible exchange rates the causation actually ran from capital inflows to trade deficit; the financing occurred first, so to speak.) And the remedy was also analogous: the budget deficit must be reduced to reduce the trade deficit, but to avoid economic recession the currency must be devalued to provide incremental external demand to compensate for the reduction in domestic demand.

One way to pose the problem is to note that the Gramm-Rudman targets entail cutting the high-employment budget deficit by about $\$ 120$ billion, roughly 3 percent of GNP, over the period 1985-88. Since the most urgent reason for reducing the budget deficit was to reduce the trade deficit, it seemed appropriate that the trade sector make up the bulk of this loss in demand.

The new Group of Five initiatives of September 22, 1985, were an attempt to address the trade balance problem by operating directly on the exchange rate. Although Gramm-Rudman had not been passed, policymakers probably contemplated a declining path for future budget deficits. The new initiatives did raise important questions. Could the dollar be depreciated without a change in fundamentals or a return to 
fixed exchange rates? If so, how far and how fast should it be encouraged to fall?

Is it possible for economic officials to "talk down" the exchange rate in opposition to the economic fundamentals? Most economists would answer with an unequivocal "no." Their models do not allow it. The more pertinent question, however, is whether the market will respond at once to changes in the fundamentals in the way that currently popular portfolio-balance rational expectations models suggest that it will. Will a credible reduction in future budget deficits really lead to an immediate and appropriate drop in long-term interest rates and depreciation of the country's currency? My guess is that the world does not work that way. Unclarities about the present and uncertainties about the future create a sluggishness in exchange market response and lead market participants to give little weight to the future beyond, say, the next year or two. ${ }^{1}$ Exchange market expectations are fragile, weakly held, and subject to crowd effects. Under these circumstances, official announcements reinforced by even modest supporting action can have a strong impact on exchange rates.

There will be a lively debate during the next few years over the respective roles in producing the sharp drop in the dollar over the past year of (1) the foreign exchange market coming to its senses, (2) improving prospects for reduction in the federal budget deficit, (3) easier U.S. monetary policy starting in early 1985 , (4) a temporary tightening of monetary policy by Japan in October 1985, (5) exchange market intervention on a considerable scale, especially by Japan, and (6) announcements of concern about the prevailing exchange rates by finance ministry

1. Some see the decline in the dollar following passage of the Gramm-Rudman bill as support for a strong link between future budget deficits and current exchange rates. But the dollar decline began nine months before passage of the act and was reinforced by a turnabout in the U.S. Treasury position on the wisdom of exchange market intervention at the Group of Five meeting of September 22, 1985. Gramm-Rudman was finally enacted into law in December 1985. A key provision was declared unconstitutional by a federal court in February 1986. Moreover, a poll of the fifty U.S. governors in March 1986 revealed that only 16 percent thought that Congress would actually enforce the Gramm-Rudman targets (Reported in Newsweek, March 24, 1986, p. 32), and the Drexell Burnham Lambert poll of 462 institutional investment decisionmakers in February (before the court decision) showed an expected budget deficit of $\$ 142$ billion in fiscal year 1990. This was down only \$24 billion from the results of a similar poll taken in June 1985 and still markedly above the Gramm-Rudman target deficit of $\$ 36$ billion for that year (reported in Decision-Makers Poll, February 14, 1986). 
officials, especially of the United States, starting in September 1985. I believe that the announcements were important, in the sense that the dollar exchange rates would not have moved so much between September 1985 and February 1986 without them. This is not to argue that the dollar would have fallen as much as it did on the strength of announcements alone.

As to the "correct" value of the dollar, a number of approaches can be used to provide ballpark estimates. Morgan Guaranty Trust's World Financial Markets regularly includes an index of the real effective exchange rate of the U.S. dollar, an index that weights the bilateral rates with fifteen other currencies by U.S. trade, after correcting for changes in each country's price index for manufactures. In February 1985 this index rose to a peak 30 percent above its 1980-82 average and 38 percent above its level in March 1973, when generalized currency floating began. By December 1985 it had fallen to 12 percent above 1980-82. Because of the timing of monthly movements, the average rate for 1985 was 3 percent above the average for 1984, despite the sharp decline later in 1985. During 1980-82 the U.S. current account was close to balance on average. Restoration of the 1980-82 real value of the dollar would require, on one calculation, exchange rates of 1.25 Canadian dollars to the U.S. dollar, 186 yen to the U.S. dollar, and 2.11 deutsche marks to the U.S. dollar for the three largest U.S. trading partners covered in the index. ${ }^{2}$

A more sophisticated calculation has been done by John Williamson using the International Monetary Fund's Multilateral Exchange Rate Model, which is weighted to take into account responsiveness of trade to changes in rates. ${ }^{3}$ Williamson targets a $\$ 12$ billion current account deficit for the United States, which would imply a swing of about $\$ 105$ billion from 1985, not quite the 3 percent of GNP required to offset the $\$ 120$ billion contraction in the full-employment budget deficit mandated by Gramm-Rudman between 1985 and 1988 . Williamson calculates that nominal rates of 198 yen and 2.04 deutsche marks to the dollar would have been the appropriate rates in the final quarter of 1984 to achieve

2. Personal communication from Rimmer de Vries.

3. John Williamson, The Exchange Rate System (Washington, D.C.: Institute for International Economics, 1985). 
the current account targets he stipulated for each of these countries. ${ }^{4}$ If Japan removed its voluntary export restraints, the corresponding exchange rates would be 182 yen and 2.09 marks to the dollar.

Williamson's figures can be used as a starting point, but they must be qualified in a number of ways. First, allowance for Japan's relative productivity growth and its external claims accumulated during 1985 would yield a somewhat lower yen-dollar rate, say 190 yen to the dollar, by the end of 1985 . Second, some allowance must be made for the fact that the observed current account deficit in 1985 reflected exchange rates prevailing one to two years earlier, and actual late 1984 exchange rates would yield a larger deficit. In that event a dollar depreciation to Williamson's equilibrium real effective exchange rate would produce a movement in the current balance somewhat larger than $\$ 105$ billion. On the other hand, the swing in the current balance wouid take several years even if the new rates were achieved immediately, and the budgetary contraction is expected to continue beyond 1988, the horizon adopted for this discussion. ${ }^{5}$ Third, Williamson assumes smaller current account surpluses and stronger domestic demand in Japan and Germany than are likely to prevail in the next few years.

Finally, the sharp drop in the price of oil in early 1986, while affecting input costs similarly in all major industrial countries, will have a strongly differential impact on the trade balances of those countries. For instance, oil in 1984 accounted for about one-third of import payments for Japan, but only 16 percent for the United States and 15 percent for Germany. Britain was a net exporter of oil. Thus the sharp drop in oil prices will have a proportionately greater positive impact on Japan's current

4. Ibid., p. 81. Williamson (pp. 82ff.) also cites estimates of equilibrium exchange rates by others, calculated in various ways. Broadly speaking, they are in the same general vicinity as Williamson's rates. The greatest disagreement concerns the yen, with several estimates being close to Williamson's, but a few others calling for a much greater appreciation of the yen.

5. Stephen Marris believes exchange rate adjustment must go much further to achieve current account balance. See Marris, Deficits and the Dollar: The World Economy at Risk (Washington, D.C.: Institute for International Economics, 1985), pp. 129, 169. But Marris allows for the large accumulation of external debt that will occur over the several years it will take to reestablish balance, whereas the objective here is to offset the contractionary fiscal impact, not to restore full current account balance. Needless to say, all these exchange rate calculations presuppose stipulated rates of growth and demand pressures in the major countries, as well as targets for the current account. 
account. Moreover, 14 percent of U.S. merchandise exports in 1984 went to oil-exporting countries, compared with 11 percent for Japan and 8 percent for Germany, so the drop in oil prices is likely to have a proportionately greater negative effect on U.S. exports. On both counts, that would require some further appreciation of the yen, to around 175, and some depreciation of the British pound.

Taking all these points together, the dollar-yen and dollar-pound rates were probably about right by April 1986, although the German mark and other EMS currencies were still undervalued by 5-10 percent. Of course, from the U.S. perspective alone, a stronger yen could compensate for a weak mark. And to the extent that neither Japan nor Germany engages in greater domestic stimulus, both currencies were still too weak for the purpose discussed here. On the other hand, the drop in oil prices will provide some stimulus to U.S. domestic demand in 1987-88, once the initial negative impact has passed.

The fall in the dollar's exchange rate has been so dramatic that it has generated some concern that the dollar would fall too far too quickly. However, I believe it has been appropriate to bring the dollar down as rapidly as possible. There are several reasons for preferring this course despite the general proposition that gradual adjustment of economic variables is normally less costly than rapid adjustment.

First, changes in monetary policy and in exchange rates affect demand for goods and services only gradually, whereas expenditure cuts affect demand rapidly. Therefore, exchange rate action must precede budget cuts.

Second, a sharp, well-defined drop in the dollar reduces foreign investors' uncertainties about future declines. Inevitably the United States will have to continue borrowing abroad during the next several years, for a cumulative total of several hundred billion dollars. So long as the dollar is expected to drop, foreigners will hesitate to lend unless U.S. interest rates are high enough to compensate for the expected decline. Yet on domestic grounds, and for the good of the world economy as well, U.S. interest rates should fall further, not rise. Thus it is preferable to have a sharp drop in the dollar and to impose the inevitable capital losses sooner rather than later. Bygones will then be bygones, and foreigners will be willing to continue to lend, even at low interest rates, on the basis of the new, cheaper dollar. 
Third, a depreciation of the dollar was necessary sooner or later, and whenever it came, it would have led to price increases for imported goods and for those domestic goods in close competition with them. The inflation gains that the United States "borrowed" from the future when the dollar appreciated so sharply have to be repaid. It is usually estimated that each 10 percent real depreciation of the dollar will lead eventually to increases in the consumer price index of 1-2 percent. Rudiger Dornbusch and Stanley Fischer estimate that the direct impact on prices is 1.25 percent, occurring after a mean lag of three quarters, with a total effect of 2.1 percent operating through induced wage increases as well. ${ }^{6}$ If the total effect is spread over two to four years, it will be lost in all of the other pressures that are also operating, and it will be impossible, without economic slack and higher unemployment, both of which are undesirable, to prevent these price increases from having their full impact on wage increases. But if the inflationary impact comes relatively quickly, as part of a deliberate and well-explained program, there is at least a chance that it will not be passed fully into wage increases. That chance is fortunately increased at present by the sharp drop in oil prices, which could greatly ease the pain of the inevitable inflationary impact of dollar depreciation. Insofar as prices do rise from a once-for-all drop in the dollar, the increase should be accompanied by a less-than-proportionate once-for-all increase in the money supply to avoid the contractionary impact of the higher prices. In short, monetary targets should be raised for 1986, but not for subsequent years.

A fourth argument for a sharp rather than a gradual drop in the dollar is that it puts early and strong pressure on other leading countries, especially Japan and Germany, to back off from their fiscal contraction and their reliance on export-led growth. These countries are too large to rely on export-led growth (over half of the new orders for capital goods in Germany during 1985 were foreign orders, substantially more than the 30 percent share of exports in Germany's GNP), especially when there are unemployed resources at home and when many countries around the world are in desperate need of export markets.

6. Rudiger Dornbusch and Stanley Fischer, "The Open Economy: Implications for Monetary and Fiscal Policy,"' in Robert J. Gordon, ed., The American Business Cycle: Continuity and Change (University of Chicago Press, forthcoming). 
An objection sometimes raised to a rapid, deliberate depreciation of the dollar is that it will get out of control and go too far. Furthermore, a sense of loss of control over a depreciating dollar might so unnerve the financial and business community that investor caution would nullify the stimulative effects of dollar depreciation. Such concern cannot be completely dismissed. It underlines the importance of how the policy is executed and the clarity with which the broad strategy, if not the specific numerical targets, must be explained. Bandwagon effects in which market sentiment derives solely from market sentiment can be influenced by official action. Moreover, a slow decline in the dollar is also subject to bandwagon effects after a time, the more so if the expected decline in the dollar is not compensated by a higher interest yield, as already noted.

The foregoing analysis assumes that the U.S. budget deficit should be gradually reduced and that, with the Gramm-Rudman act, the deficit is on a declining path. However, exclusive reliance on expenditure cuts is not the best way to reduce the deficit. Indeed, one wonders whether President Reagan has ever troubled to look at the numbers involved. If one protects from cuts both defense and social security, as he desires, and also interest payments, as everyone takes for granted, then in fiscal year 1986 only an estimated $\$ 282$ billion in government expenditures remain, as against a projected deficit, before automatic Gramm-Rudman cuts, of $\$ 220$ billion. In other words, to eliminate the deficit exclusively by cutting unprotected expenditures would require virtual elimination of government beyond the Defense Department and a bare-bones Department of Health and Human Services. Eighty percent of the remainder-law enforcement, foreign affairs, highways and airports and parks, welfare and health programs (other than medicare), space, energy, agriculture, and so on-would have to go. This is not going to happen. Either defense and social security will have to be cut consequentially, or some form of tax increase will be necessary.

Viewed from the perspective of last fall, macroeconomic policy for the United States required a firm commitment to reduce the federal budget deficit, but gradually so as to permit actions that would avoid a recession; a tax increase as a part of the fiscal action; expansionary monetary policy to help counteract the contractionary fiscal action; and a sharp drop in the value of the dollar brought about partly by exchange market intervention and partly by jawboning.

Some of these policy actions have already been taken or are under 
way. The drop in the dollar is an essential part of this policy package, and the specific actions taken last September have been appropriate and effective. The dollar's decline will help offset the fiscal contraction through expansion of net exports, help maintain overall U.S. economic activity at a satisfactory level, and head off the strong protectionist pressures that, in the peculiar political circumstances of 1986, might erupt into damaging protectionist action. 